\title{
Análisis de Ciclo de Vida para el ecodiseño del sistema Intemper TF de cubierta ecológica aljibe
}

\section{Life Cycle Assessment for ecodesign of ecological roof made with Intemper TF ecological water-tank system}

\author{
B. Rivela $(*)$, I. Cuerda(*), F. Olivieri(*), C. Bedoya(*), J. Neila(*)
}

Recepción/Received: 5-V-11

Aceptación/Accepted: 10-X-11

Publicado online/Online publishing: 16-II-12

\section{RESUMEN}

El sector de la construcción representa una de las actividades menos sostenibles del planeta: consume el $40 \%$ de los materiales de la economía global y genera el 40$50 \%$ de las emisiones de gases de efecto invernadero. El mayor impacto ambiental de los edificios se genera durante su fase de uso, debido al gasto energético de su acondicionamiento térmico. El uso de elementos vegetales es una de las estrategias empleadas para aumentar la eficiencia energética. En este trabajo se ha empleado la metodología de Análisis de Ciclo de Vida (ACV) para cuantificar el impacto ambiental de los materiales de la cubierta vegetal. Se han identificado los puntos críticos del sistema para establecer una estrategia de ecodiseño y reducir eficazmente las cargas ambientales. Los resultados obtenidos muestran la importancia del impacto ambiental del soporte estructural, la elevada contribución de la mecha de riego de fieltro y del aislamiento de poliestireno extrudido.

Palabras clave: sostenibilidad; cubiertas ecológicas; ecodiseño; eficiencia energética; Análisis de Ciclo de Vida (ACV).

\section{SUMMARY}

The construction industry is one of the less sustainable activities on the planet: with a consumption of $40 \%$ of the materials entering the global economy and the generation of $40-50 \%$ of the global output of greenhouse gases. The biggest environmental impact caused by buildings is generated during their use phase due to the energy consumption for thermal conditioning. Addition of green elements to buildings is used to improve energy efficiency of buildings. In this study Life Cycle Assessment (LCA) methodology has been applied to quantify the environmental impact of the green roofs materials to analyze its environmental profile. The identification of hot spots of the system permits an ecodesign strategy that effectively reduces environmental burdens associated with roof construction, optimizing the environmental performance. The results identify the high environmental impact associated to the structure, the important contribution of the felt wick irrigation system and the extruded polystyrene thermal insulation.

Keywords: sustainability; ecological roofs; ecodesign; energy efficiency; Life Cycle Assessment (LCA).

(*) Universidad Politécnica de Madrid (Madrid, España). 


\section{INTRODUCCIÓN}

En el momento actual, la contaminación y degradación de los ecosistemas, el agotamiento de los recursos, la pérdida de diversidad biológica y cultural y el calentamiento global del planeta son algunos ejemplos de la complejidad de los problemas ambientales que en las últimas décadas se han incorporado, cada vez con mayor urgencia, a la agenda de los planes y programas de organismos nacionales e internacionales. Especialmente grave ha sido la constatación por el Grupo Intergubernamental de Expertos de Cambio Climático (IPCC) de que el calentamiento global es inequívoco (1). La preservación del medio ambiente se ha convertido en elemento movilizador de importantes sectores sociales, tanto en el ámbito gubernamental como en la propia sociedad civil. Las preocupaciones del pasado han adquirido cierta urgencia que sitúa hoy en día a la temática ambiental en el eje central del desarrollo económico.

El sector de la construcción afronta el reto de la sostenibilidad desde una posición paradigmática: la industria de la construcción mundial consume el $40 \%$ de los materiales que forman parte de la economía global y genera entre el 40 y el $50 \%$ de las emisiones de gases de efecto invernadero y de agentes causantes de la lluvia ácida, lo que le convierte en una de las actividades menos sostenibles del planeta (2). El principal desafío de este siglo reside en el margen que separa el poder de que dispone la humanidad y la sabiduría que es capaz de demostrar en su utilización (3). La existencia de la civilización contemporánea depende de una construcción definitivamente insostenible para el planeta; es evidente que los planteamientos deben cambiar y el papel que debe desempeñar el sector de la construcción es crucial en ese proceso de cambio.

El mayor impacto ambiental producido por los edificios se genera durante su fase de uso y está ocasionado principalmente por el gasto energético relacionado con su acondicionamiento térmico (4). Por ello, aumentar la eficiencia energética de los edificios constituye un factor clave para disminuir su impacto ambiental. Entre las numerosas estrategias empleadas para la reducción de los consumos energéticos de la edificación, cabe destacar el potencial que ofrece la introducción de elementos vegetales, cuyo empleo se ha generalizado en los últimos años en países como Alemania, Suiza o Canadá, por las diferentes ventajas que su comportamiento proporciona (5). Entre estas ventajas $(6,7)$, cabe destacar como principales beneficios, el ahorro energético y económico en climatización, el aislamiento acústico, el ahorro económico en infraestructuras para aguas pluviales, la mejora de la calidad del aire, la reducción del efecto de la isla de calor en áreas urbanas, el aumento del hábitat para fauna y flora urbana y la realización de áreas de

\section{INTRODUCTION}

In the present time, the pollution and degradation of the ecosystems, the resources depletion, the loss of biological and cultural diversity and the planet's global warming are a few examples of the complexity of the environmental problems which have been added during the last decades, with growing urgency, to the agenda of plans and programmes of national and international organizations. The ascertainment by the Intergovernmental Panel on Climate Change (IPCC) that global warming is unequivocal has been especially serious (1). The preservation of environment has become a mobilising agent for important social groups, both within the government sphere as well as in the civil society itself. The concerns from the past have gained a certain urgency which places nowadays the environmental subject matter in the focal point of the economic development.

The construction sector faces the challenge of sustainability from a paradigmatic position: the world construction industry consumes $40 \%$ of the materials which are part of the global economy and generates between 40 and $50 \%$ of the emissions of greenhouse gases and the agents responsible of the acid rain, which make it one of the least sustainable activities of the planet (2). The major challenge of this century lies in the ground between the power which humankind has at its disposal and the wisdom which it is capable of showing in using it (3) The existence of contemporary civilization depends on a type of construction definitely unsustainable for the planet; it is clear that the approaches must change and the part that the construction sector must play in that change is crucial.

The greatest environmental impact caused by buildings is generated during their use phase and it's brought about mainly by the energy expenditure related to its thermal conditioning (4). For that reason, increasing the energy efficiency in buildings constitutes a key factor to reduce their environmental impact. Among the many strategies used for the reduction of building energy consumption, the potential offered by the insertion of vegetation is worth noting. Its use has spread in recent years in countries such as Germany, Switzerland or Canada, because of the different advantages that its performance provides (5). Worth emphasizing among these advantages $(6,7)$, as main benefits, are the energy and economical savings in conditioning, the acoustic insulation, the economical savings in infrastructures for stormwater, the air quality improvement, the reduction of the urban heat island effect in urban areas, the increase of the habitat for urban fauna and flora and the implementation 
recreación en la cubierta, aumentando el valor de la propiedad.

El estudio de las cubiertas ecológicas como material de construcción ha sido extensamente abordado como estrategia de reducción del impacto ambiental, centrando la atención en el análisis del comportamiento térmico y energético del edificio. Los resultados obtenidos han sido muy favorables en relación a los ahorros energéticos alcanzados, especialmente en condiciones de verano (8-11). Sin embargo, la evaluación del comportamiento ambiental del sector de la construcción, especialmente compleja, no puede verse limitada a la fase de vida útil de los objetos construidos. Los edificios, en comparación con otros "productos", presentan una serie de dificultades añadidas a la hora de abordar su análisis. La diversidad de materiales y funciones o el comportamiento dinámico de sus componentes, constituyen algunos de los elementos que justifican esta complejidad. Los procesos de producción asociados a un edificio están muchos menos estandarizados que la mayoría de los bienes manufacturados de mercado, y de algún modo se podría hablar del carácter único de cada edificación. Por otra parte, la información disponible sobre el impacto ambiental de la producción y manufactura de los materiales de construcción es limitada, así como la información de los procesos actuales de construcción y demolición. En este contexto, se hace necesario implementar estrategias que contribuyan al ahorro de energía -y por lo tanto, a la reducción de las emisiones de gases de efecto invernadero- y evaluar estas estrategias en su ciclo de vida completo, para verificar que el beneficio obtenido en la reducción de emisiones no se traduce en la introducción de nuevos impactos en otros campos.

Desde el año 2000, el número de métodos para la evaluación medioambiental de edificios en el mundo se ha multiplicado considerablemente (12). En lo relativo al comportamiento ambiental global, la metodología que se presenta como más adecuada para su cuantificación es el Análisis de Ciclo de Vida (ACV) (13). El ACV es una metodología que permite sistematizar la adquisición y generación de información y objetiva las decisiones a tomar hacia un deseable desarrollo sostenible, presentándose como una herramienta clave en la selección de procesos, optimización y diseño. La norma UNE-EN ISO 14.040:2006 define el ACV como: "una técnica para evaluar los aspectos medioambientales y los potenciales impactos asociados con un producto, mediante la recolección de un inventario de las entradas y salidas relevantes de un sistema; la evaluación de los potenciales impactos medioambientales asociados con esas entradas y salidas; y la interpretación de los resultados de las fases de análisis y evaluación de impacto de acuerdo con los objetivos del estudio" (14). Su aplicación se ha generalizado al of recreation areas on the roof, increasing the value of the property.

The study of ecological roofs as a construction material has been extensively tackled as an environmental impact reduction strategy, focusing the attention on the analysis of the building's thermal and energy performance. The results obtained have been quite favourable in relation to the energy savings reached, especially in summertime conditions (8-11). However the assessment of the environmental performance of the construction sector, particularly complex, can't be limited to the service life of the built objects. Buildings, compared to other "products", bring forward a series of added difficulties when it comes to tackle their analysis. The diversity of materials and functions or the dynamic performance of their components makes up some of the elements which justify this complexity. The production processes associated to a building are much less standardized than most of the manufactured goods of the market, and somehow the unique nature of each building could be spoken about. On the other hand, the information available on the environmental impact of the production and manufacture of construction materials is limited, as well as the information about the current construction and demolition processes. In this context, implementing new strategies which contribute to energy savings -and therefore to the emissions of greenhouse gases' reduction- and assessing these strategies in their complete life cycle becomes necessary, in order to verify that the benefit obtained in the reduction of emissions does not translate into the introduction of new impacts in other fields.

Since year 2000, the number of methods for environmental assessment of buildings in the world has multiplied considerably (12). With regard to the global environmental performance, the methodology presented as the most suitable for its quantification is the Life Cycle Assessment (LCA) (13). LCA is a methodology which makes possible the systematization of information acquisition and generation and objectifies the decisions to make toward a desirable sustainable development, coming up as a key tool in the selection of processes, optimization and design. Standard UNE-EN ISO 14.040:2006 defines LCA as: "a technique to assess the environmental aspects and the potential impacts associated with a product, by means of the collection of an inventory of the relevant inputs and outputs of a system; the assessment of the potential environmental impacts associated with these inputs and outputs; and the interpretation of the results of the analysis and impact evaluation phases according to the study objectives" (14). Its application has spread in the frame of environmental 
marco de definición de políticas ambientales, constituyendo la piedra angular de la Política Integrada de Productos, la Estrategia Temática sobre Prevención y Reciclado de Residuos y la Estrategia Temática sobre el Uso Sostenible de los Recursos Naturales. La Unión Europea ha señalado el ACV como la mejor herramienta para evaluar el potencial impacto ambiental de los productos, creando la "European Platform of Life Cycle Assessment" para promover el empleo de la herramienta.

En el ámbito específico de la construcción, el Comité CEN/TC 350 "Sustainability of construction works", responsable del desarrollo de la futura norma europea de evaluación de la sostenibilidad de los edificios, ha establecido el ACV como la metodología de referencia para el marco de trabajo de los métodos de evaluación del comportamiento ambiental (15-17).

En el presente estudio se ha empleado la metodología de ACV con el objetivo de cuantificar el impacto ambiental de los materiales que componen la cubierta vegetal, analizando en profundidad el perfil ambiental de la cubierta y las repercusiones ambientales que conlleva su implementación en los diferentes contextos climáticos de España. La identificación de los puntos críticos del sistema permitirá establecer una estrategia de ecodiseño que reduzca eficazmente las cargas ambientales asociadas a la construcción de la cubierta.

\section{METODOLOGÍA}

La composición de la cubierta y la caracterización de los materiales han sido analizadas en diferentes ubicaciones, correspondientes a las distintas zonas climáticas del Código Técnico de la Edificación (CTE DB HE1). En cada zona climática, el CTE determina, para los cerramientos de la envolvente del edificio, un valor de transmitancia máxima, con el fin de asegurar un aislamiento mínimo en todos los edificios. La zona climática de invierno (definida con una letra) es la que determina el valor de los parámetros de transmitancia máxima del CTE. Con el objetivo de cubrir el espectro de las diferentes zonas climáticas de invierno, se han seleccionado cinco ciudades, emplazadas en cada una de las cinco zonas definidas por el CTE: Cádiz, Valencia, Vigo, Madrid y Soria. La cubierta se ha adaptado, manteniendo fija su configuración y variando el espesor del aislamiento en cada caso, asegurando el cumplimiento de los límites fijados por el CTE en cada zona climática.

El Análisis de Ciclo de Vida (ACV) ha sido empleado para la cuantificación del impacto ambiental de los materiales politics definition, representing the cornerstone of the Integrated Product Policy, the Thematic Strategy on the Prevention and Recycling of Waste and the Thematic Strategy on the Sustainable Use of Natural Resources. The European Union has appointed LCA as the best tool to assess the potential environmental impact of the products, creating the "European Platform of Life Cycle Assessment" in order to promote the use of the tool.

In the specific field of construction, Committee CEN/TC 350 "Sustainability of construction works", responsible for the development of the future building sustainability assessment European standard, has established LCA as the reference methodology for the environmental performance assessment methods framework (15-17).

LCA methodology has been used in this study with the aim of quantifying the environmental impact of the materials which make up the green roof, analysing in depth the environmental profile of the roof and the environmental repercussions that its implementation in the different climate contexts of Spain entails. The identification of the critical points of the system makes possible to establish an ecodesign strategy which will effectively reduce the environmental burdens associated with the roof's construction.

\section{METHODOLOGY}

The composition of the roof and the characterization of the materials have been analysed in different locations, corresponding to the different climate zones of the Technical Building Code (Código Técnico de la Edificación, CTE DB HE1). In each climate zone, the CTE determines, for the enclosures of the envelope of the building, a transmittance maximum value, in order to ensure a minimum insulation in all the buildings. The winter climate zone (defined with a letter) is the one that determines the value of the CTE's maximum transmittance parameters. Aiming to cover the range of the different winter climate zones, five cities have been selected, located in each one of the five zones defined by the CTE: Cádiz, Valencia, Vigo, Madrid and Soria. The roof has been adapted, keeping its configuration unaltered and varying the insulation's thickness in each case, guaranteeing the compliance of the limits fixed by the CTE for each climate zone.

Life Cycle Assessment ( $L C A$ ) has been used for the quantification of the environmental impact of the materials 
involucrados en la construcción de la cubierta, desde la extracción de las materias primas hasta la salida de fábrica de los materiales (lo que se denomina análisis de "cuna a puerta"), considerando todos los flujos de materia y energía involucrados en la producción de los componentes de la instalación, con el objetivo de analizar y evaluar las cargas ambientales asociadas a la fabricación de la cubierta ecológica.

La unidad funcional, que permite la cuantificación de la función del sistema analizado y constituye la unidad de referencia en el estudio (14), se ha establecido como "un metro cuadrado de una cubierta plana invertida con pavimento flotante de baldosa para uso peatonal privado". Para el cálculo del soporte estructural, se ha considerado su instalación sobre un edificio comercial, puesto que el empleo de cubiertas vegetales en este tipo de edificios está muy extendido (18).

El cálculo del perfil ambiental se ha realizado conforme a la metodología CML 2000, una actualización del método CML publicado en 1992 por el Centre of Environmental Science de la Universidad holandesa de Leiden (19), que representa el estado del arte de las denominadas metodologías "midpoint" o de impactos de efecto intermedio. Estas metodologías, enfocadas al problema y no al daño final, tienen como resultado la definición de un perfil ambiental mediante la cuantificación del efecto ambiental sobre diversas categorías (acidificación, destrucción de la capa de ozono, etc.), del producto / proceso / servicio objeto de estudio. En el estudio se han analizado los resultados obtenidos para todas las categorías de impacto, si bien es aconsejable prestar especial atención a las categorías de impacto para las que existe un mayor consenso en los referentes de ACV a nivel internacional, tanto en el ámbito científico como de desarrollo normativo. Estas categorías, reflejadas en la Tabla 1, son las contempladas por la Organización Internacional de Estandarización (ISO) en la norma ISO 21930, el Comité CEN (Comité Europeo de Estandarización) y el Sistema de referencia internacional de datos de ciclo de vida de la plataforma europea de ACV (International Reference Life Cycle Data System) desarrollado por el Joint Research Centre - Institute for Environment and Sustainability (20-22).

El esquema de composición de la cubierta analizada se muestra en la Figura 1. Para poder abordar el análisis de los resultados con mayor profundidad, se ha dividido el sistema de cubierta en subsistemas, atendiendo a la función que los distintos elementos que la conforman desempeñan en la cubierta.

Las plantas empleadas en la vegetación de este tipo de cubiertas varían en función de las condiciones climáticas involved in the roof's construction, from the extraction of the raw materials to the materials' dispatch from the manufacture (known as "cradle to gate" analysis), taking into account all the matter and energy flows involved in the production of the system components, with the objective of analysing and assessing the environmental burdens / loads associated with the fabrication of the ecological roof.

The functional unit, which makes possible the quantification of the analysed system function and constitutes de reference unit in the study (14), has been established as "one square meter of a reverted flat roof with tile floating floor for private pedestrian use". Its installation over a commercial building has been taken into account when calculating the structural support, as the use of green roofs in this type of buildings is widely spread (18).

The environmental profile calculation has been done according to the CML 2000 methodology, an update of the CML method published in 1992 by the Institute of Environmental Science of the Dutch University of Leiden (19), which represents the state of the art of the socalled "midpoint" methodologies. These methodologies, focused on the problem and not on the final damage, have as a result the definition of an environmental profile by means of the quantification of the environmental effect on various categories (acidification, ozone layer depletion, etc.), of the product / process / service object of study. The results obtained for all the impact categories have been analysed in the study, although paying special attention to the impact categories for which a larger consensus in the LCA referents exists worldwide, both in the scientific and the standard development fields, is encouraged. These categories, shown in Table 1, are those considered by the International Organization for Standardization (ISO) in standard ISO 21930, the CEN Committee (European Committee for Standardization) and the International Reference Life Cycle Data System developed by the Joint Research Centre - Institute for Environment and Sustainability (20-22).

The composition diagram of the analysed roof is shown in Figure 1. In order tackle the analysis of the results in greater depth, the roof system has been divided in subsystems, in accordance with the role played in the roof by the different elements which form the subsystem.

The plants used in the vegetation of this type of roofs vary according to the climate conditions of the location 
Tabla 1 / Table 1

Categorías de impacto consensuadas.

Impact categories.

\begin{tabular}{|c|c|c|}
\hline Categoría / Category & EN 15804 & ISO 21930 \\
\hline Calentamiento global / Global warming & $\mathrm{x}$ & $\mathrm{x}$ \\
\hline Agotamiento ozono estratosférico / Ozone layer depletion & $\mathrm{x}$ & $\mathrm{x}$ \\
\hline Eutrofización / Eutrophication & $\mathrm{x}$ & $\mathrm{x}$ \\
\hline Formación ozono fotoquímico / Photochemical oxidation & $\mathrm{x}$ & $\mathrm{x}$ \\
\hline Agotamiento recursos no renovables / Abiotic depletion & $\mathrm{x}$ & $\mathrm{x}$ \\
\hline Toxicidad humana / Human toxicity & $\mathrm{x}$ & \\
\hline Radiación ionizante / Radiation & & \\
\hline Uso del suelo / Land use & & $\mathrm{x}$ \\
\hline & & $\mathrm{x}$ \\
\hline
\end{tabular}

1 Consumo de recursos / Resource depletion

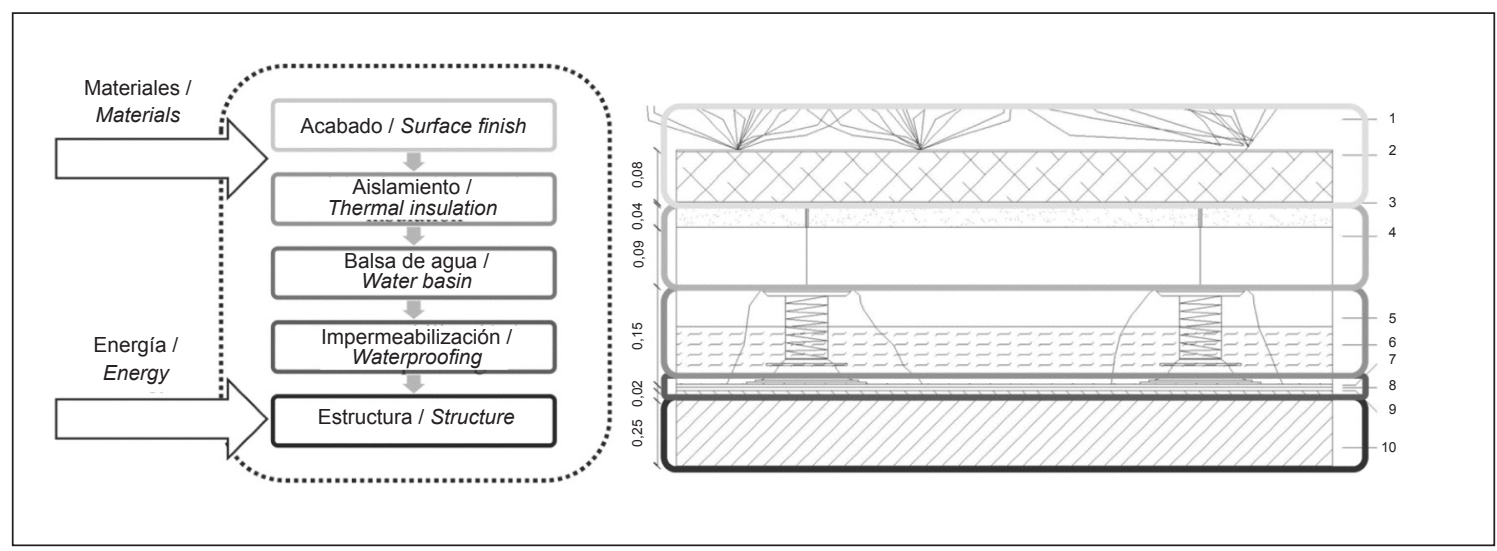

Figura 1. Esquema de la cubierta ecológica realizada con el sistema Intemper TF ecológico aljibe. 1. Vegetación. 2. Sustrato. 3. Fieltro sintético F150. 4. Losa Filtrón. 5. Soportes. 6. Balsa de agua. 7. Lámina de PVC. 8. Fieltro sintético F300. 9. Mortero de regulación. 10. Forjado reticular (cotas en metros).

Figure 1. Description of the Intemper TF Ecological Water-Tank System. 1. Vegetation. 2. Soil. 3. Felt sheet 150. 4. Concrete tile with extruded polystyrene. 5. Pedestals. 6. Water basin. 7. PVC membrane. 8. Felt sheet 300. 9. Cement mortar. 10. Concrete slab (dimensions in meters).

del lugar donde se va a construir. Para este estudio, se seleccionaron las especies Carex Testacea y Stipa tenuísima "nasella". El sustrato está compuesto por una mezcla de materia vegetal, saulo mineral y abono orgánico. El fieltro sintético, que se emplea como mecha de riego para la vegetación, es de fibra de poliéster. La Losa Filtrón, fabricada por la empresa Intemper, está compuesta por una capa de hormigón poroso y otra de material aislante, poliestireno extrudido. Los soportes de las losas son de polipropileno. La lámina impermeabilizante es de PVC. El mortero de regulación se emplea para regularizar la superficie del soporte estructural antes de colocar sobre ella los demás elementos de la cubierta.

\section{RESULTADOS Y DISCUSIÓN}

Los datos sobre el diseño y materiales empleados han sido recopilados durante el año 2009 y corresponden a una instalación estándar en la Península Ibérica, where it is going to be built. For this study, the species Carex Testacea and Stipa tenuissima "nasella" were selected. The substrate is composed by a mixture of plant material, mineral saulo and organic fertilizer. The synthetic felt, used as irrigation wick for the plants, is of polyester fibre. The Filtrón Slab, manufactured by the company Intemper, is composed of a porous concrete layer and another one of insulant material, extruded polystyrene. The supports of the slabs are in polypropylene. The waterproofing sheet is in PVC. The levelling mortar is used to level the surface of the structural support before placing on it the rest of the roof's elements.

\section{RESULTS AND DISCUSSION}

The information about the design and materials used has been gathered during year 2009 and correspond with a standard installation in the Iberian Peninsula, $29250 \mathrm{~m}^{2}$ 
habiéndose ejecutado en los últimos diez años $29.250 \mathrm{~m}^{2}$. Como se mencionó anteriormente, la definición del sistema a estudiar se ha realizado adaptando el sistema de cubierta a los condicionantes que impone el Código Técnico de la Edificación (CTE) para cada área geográfica y determinando el soporte estructural objeto de análisis. Se ha realizado la evaluación para las 5 áreas climáticas de invierno que determina el CTE (ciudades de Cádiz, Valencia, Vigo, Madrid y Soria, cada una representativa de una de las citadas zonas climáticas). La adaptación de la cubierta a este requerimiento se realiza ajustando el espesor de aislamiento térmico, de forma que sea suficiente para que la cubierta tenga ese valor mínimo de transmitancia (Tabla 2). La elección del soporte estructural, un forjado reticular, se ha realizado tomando en consideración el edificio comercial seleccionado. Las características de los elementos que forman el acabado de la cubierta están determinadas por normativa en función del uso para el que está destinada. having been done in the last ten years. As aforementioned, the definition of the system to study was made adapting the roof system to the conditions determined by the Technical Building Code (CTE) for each geographical area and determining the structural support object of analysis. The assessment has been carried out for the 5 winter climate areas determined by the CTE (cities of Cádiz, Valencia, Vigo, Madrid and Soria, each one representative of one of the aforementioned climate areas). The adaptation of the roof to this requirement is done by adjusting the thermal insulation's thickness, in such a way that it is enough so that the roof reaches that minimum transmittance value (Table 2). The choice of structural support, a waffle slab, was made taking into account the commercial building selected. The characteristics of the elements which make up the roof's finishing are determined by regulations depending on the use for which it is destined.

Tabla 2 / Table 2

Aislamiento para diferentes zonas climáticas.

Thermal insulation for different climatic areas.

\begin{tabular}{|c|c|c|c|}
\hline Zonas climáticas / Climatic areas & $\begin{array}{c}\text { Espesor aislamiento / } \\
\text { Insulation thickness }(\boldsymbol{m})\end{array}$ & $\begin{array}{c}\text { Resistencia / } \\
\text { Resistance }\left(\boldsymbol{m}^{\mathbf{2}} \mathbf{K} / \boldsymbol{W}\right)\end{array}$ & $\begin{array}{c}\text { Transmitancia / } \\
\text { Transmittance }\left(\boldsymbol{W} / \boldsymbol{m}^{\mathbf{2}} \boldsymbol{K}\right)\end{array}$ \\
\hline Cádiz. Zona / Area A3<0.5 & 0.05 & 2.24 & 0.446 \\
\hline Valencia. Zona / Area B3<0.45 & 0.05 & 2.24 & 0.446 \\
\hline Vigo. Zona / Area C1<0.41 & 0.06 & 2.55 & 0.390 \\
\hline Madrid. Zona / Area D3<0.38 & 0.07 & 2.84 & 0.350 \\
\hline Soria. Zona / Area E1<0.35 & 0.08 & 3.14 & 0.320 \\
\hline
\end{tabular}

Tabla 3 / Table 3

Datos de inventario de $1 \mathrm{~m}^{2}$ de cubierta ecológica. Inventory data of $1 \mathrm{~m}^{2}$ ecological roof.

\begin{tabular}{|c|c|c|c|}
\hline Función / Function & Elemento / Element & $\mathrm{kg} / \mathrm{m}^{2}$ & $\begin{array}{l}\mathrm{kg} / \mathrm{kg} \text { totales / } \\
\mathrm{kg} / \text { total } \mathrm{kg}(\%)\end{array}$ \\
\hline \multirow[t]{3}{*}{ Acabado superficial / Surface finish } & 1. Vegetación / Vegetation & 1.00 & $0.13 \%$ \\
\hline & 2. Sustrato / Soil & 47.87 & $6.11 \%$ \\
\hline & 3. Fieltro sintético / Felt sheet & 0.26 & $0.03 \%$ \\
\hline \multirow[t]{2}{*}{ Aislamiento / Thermal insulation } & 4. Losa Filtrón / Concrete tile with extruded polystyrene & 69.71 & $8.90 \%$ \\
\hline & 5. Soportes / Pedestals & 1.41 & $0.18 \%$ \\
\hline Balsa de agua / Water basin & 6. Balsa de agua / Water basin & 140.00 & $17.88 \%$ \\
\hline \multirow[t]{3}{*}{ Impermeabilización / Waterproofing } & 7.Lámina PVC / PVC membrane & 1.55 & $0.20 \%$ \\
\hline & 8. Fieltro sintético / Felt sheet & 0.30 & $0.04 \%$ \\
\hline & 9. Mortero de regulación / Cement mortar & 50.17 & $6.41 \%$ \\
\hline \multirow[t]{2}{*}{ Soporte estructural / Structure } & 10. Forjado reticular / Concrete slab & 470.72 & $60.12 \%$ \\
\hline & TOTAL & 785.11 & $100.00 \%$ \\
\hline
\end{tabular}

Los balances de materia y energía de los distintos materiales que componen los elementos de la cubierta han sido obtenidos a través de la búsqueda y selección de los materiales más adecuados en la base de datos Ecoinvent (23). En la Tabla 3 se presenta un resumen
The balance of matter and energy of the different materials which compose the roof's elements have been obtained by means of the search and selection of the most suitable materials in the Ecoinvent database (23). A summary of the quantification of the elements 
de la cuantificación de los elementos que componen la cubierta, agrupados conforme a los subsistemas definidos. La composición del sustrato (materia vegetal, saulo mineral y abono orgánico), la composición y peso de los fieltros Feltemper 150 y 300 (filamentos continuos de poliéster) y la información sobre la losa Filtrón $\left(67,40 \mathrm{~kg} / \mathrm{m}^{2}\right.$ de hormigón poroso y $2,31 \mathrm{~kg} / \mathrm{m}^{2}$ de poliestireno extrudido) han sido facilitados por la empresa Intemper. Para calcular la cantidad de materiales involucrados en un metro cuadrado de forjado, se ha considerado que la planta de cubierta, que presenta una luz entre soportes de $8 \mathrm{~m}$, se resuelve mediante el empleo de un forjado bidireccional, con una modulación de $82 \times 82 \mathrm{~cm}$, bloque permanente de poliestireno expandido de $70 \times 70 \mathrm{~cm}$, nervio de $12 \mathrm{~cm}$ de ancho por $30 \mathrm{~cm}$ de alto y una capa de compresión de $5 \mathrm{~cm}$ de espesor, con un mallazo $\varnothing 5$ a 100. En el perímetro de los pilares el forjado está reforzado y su canto aumenta en $5 \mathrm{~cm}$, duplicando la capa de compresión. Se ha estudiado un módulo estructural de $8 \mathrm{~m} \times 8 \mathrm{~m}$, identificando los 3 elementos que forman el forjado (viga, forjado de $35 \mathrm{~cm}$ y forjado de $40 \mathrm{~cm}$ ) y su repercusión sobre un metro cuadrado. La composición final obtenida, representativa del conjunto del forjado, es la siguiente: $344,67 \mathrm{~kg} / \mathrm{m}^{2}$ de áridos, $54,58 \mathrm{~kg} / \mathrm{m}^{2}$ de cemento, $35,21 \mathrm{~kg} / \mathrm{m}^{2}$ de agua, $33,56 \mathrm{~kg} / \mathrm{m}^{2}$ de armadura de acero y $2,70 \mathrm{~kg} / \mathrm{m}^{2}$ de poliestireno expandido.

\subsection{Caracterización}

En la fase de evaluación, los resultados del inventario (entradas y salidas de flujos al medio ambiente) se clasifican en función de la/s categoría/s de impacto ambiental a las que contribuyen. Posteriormente, la caracterización consiste en la aplicación de modelos para obtener un indicador ambiental en cada categoría de impacto, unificando a una única unidad de referencia todas las sustancias clasificadas dentro de cada categoría mediante el empleo de factores de equivalencia.

Los resultados de caracterización de la cubierta ecológica con la metodología CML 2000 se muestran en la Figura 2, presentando, para cada una de las categorías de impacto analizadas, la contribución porcentual de los diferentes subsistemas. La figura muestra los resultados de la configuración de la cubierta en la ciudad de Madrid; si bien la distribución del impacto entre subsistemas presenta un perfil similar en el resto de las ciudades, las variaciones producidas como consecuencia de la adaptación de la cubierta serán posteriormente comentadas a partir de los resultados de la evaluación de escenarios. En la Figura 2 se observa que el subsistema "soporte estructural" es el responsable de la mayor contribución en todas las categorías de impacto, con la excepción de la categoría de "Agotamiento de la capa de ozono", en la que el subsistema de "aislamiento" presenta una contribución del 95\%. composing the roof is shown in Table 3, grouped according to the defined subsystems. The composition of the substrate (plant material, mineral saulo and organic fertilizer), the composition and weight of the Feltemper 150 and 300 felts (polyester continuous filaments) and the information about the Filtrón slab $\left(67.40 \mathrm{~kg} / \mathrm{m}^{2}\right.$ of porous concrete and $2.31 \mathrm{~kg} / \mathrm{m}^{2}$ of extruded polystyrene) have been provided by the company Intemper. In order to calculate the quantity of materials involved in a square meter of slab, the roof floor, which presents an $8 \mathrm{~m}$ span between supports, is considered to have been solved by means of a two-way slab, with a $82 \times 82 \mathrm{~cm}$ modulus, 70 $x 70 \mathrm{~cm}$ expanded polystyrene permanent block, $12 \mathrm{~cm}$ wide and $30 \mathrm{~cm}$ high rib and a $5 \mathrm{~cm}$ thick compression coat, with a welded wire mesh $\varnothing 5$ at 100. In the perimeter of the pillars the slab is reinforced and its thickness increases $5 \mathrm{~cm}$, doubling the compression coat. An $8 \times 8$ $m$ structural modulus has been studied, identifying the 3 elements forming the slab (beam, $35 \mathrm{~cm}$ slab and $40 \mathrm{~cm}$ slab) and their repercussion on one square meter. The final composition obtained, representative of the whole slab, is as follows: $344.67 \mathrm{~kg} / \mathrm{m}^{2}$ aggregates, $54.58 \mathrm{~kg} / \mathrm{m}^{2}$ cement, $35.21 \mathrm{~kg} / \mathrm{m}^{2}$ water, $33.56 \mathrm{~kg} / \mathrm{m}^{2}$ steel reinforcement and $2.70 \mathrm{~kg} / \mathrm{m}^{2}$ expanded polystyrene.

\subsection{Characterization}

In the assessment phase, the inventory results (flows inputs and outputs to the environment) are classified according to the environmental category / ies to which they contribute. Subsequently, the characterization involves the application of models to obtain an environmental indicator in each impact category, unifying into an only reference unit all the substances classified within each category by using equivalence factors.

The characterization results of the ecological roof with the CML 2000 methodology are shown in Figure 2, presenting, for each one of the impact categories analysed, the percentage contribution of the different subsystems. The figure shows the results of the roof configuration in the city of Madrid; although the distribution of the impact between subsystems presents a similar profile in the rest of cities, the variations occurred as a consequence of the roof adaptation will be subsequently discussed from the results of the scenarios assessment. Figure 2 shows that the "structural support" subsystem is responsible of the largest contribution in all the impact categories, with the exception of the "Ozone layer depletion" category, in which the "insulation" subsystem presents a contribution of $95 \%$. 


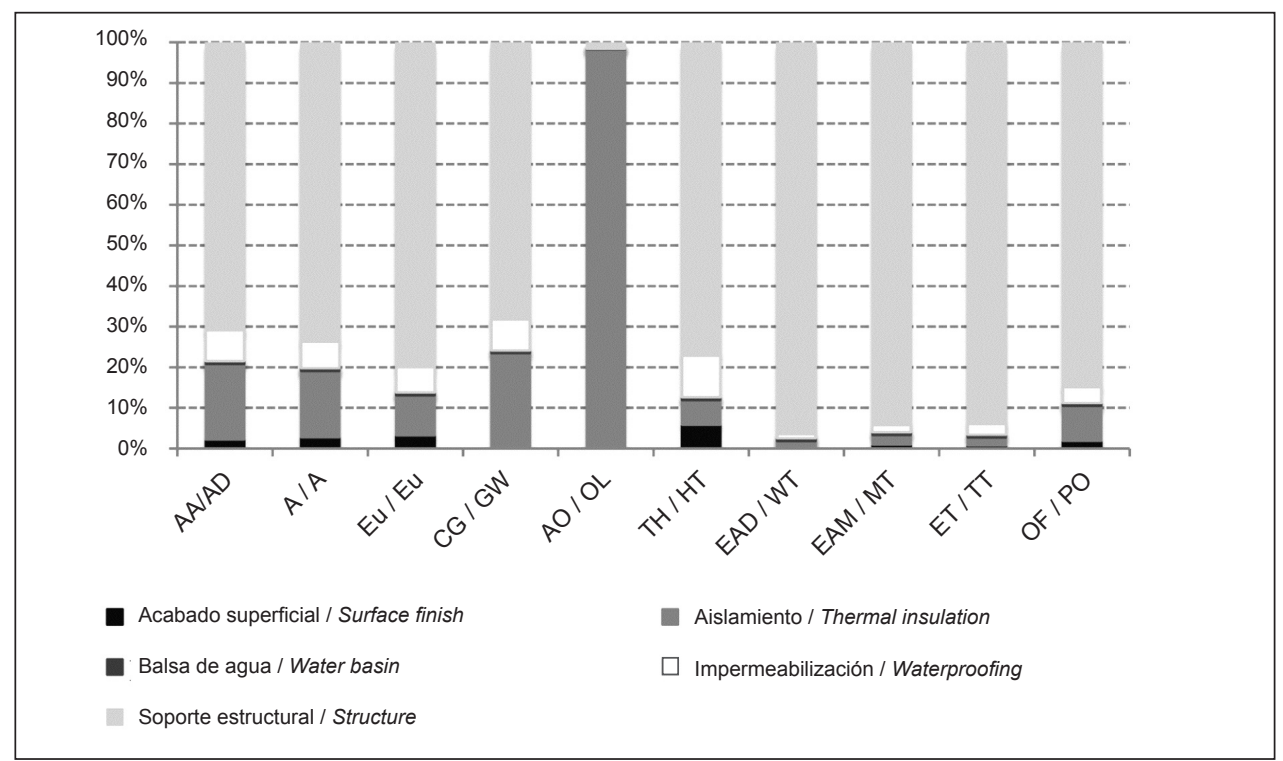

Figura 2. Perfil ambiental de la cubierta - Caracterización CML 2000. AA: Agotamiento de recursos abióticos; A: Acidificación; Eu: Eutrofización; CG: Calentamiento global; AO: Agotamiento de la capa de ozono; TH: Toxicidad humana; EAD: Ecotoxicidad acuática de agua dulce; EAM: Ecotoxicidad acuática marina; ET: Ecotoxicidad terrestre; OF: Oxidación fotoquímica.

Figure 2. Environmental profile of the roof - Characterisation results with CML 2000. AD: Abiotic depletion; A: Acidification; E: Eutrophication; GW: Global warming; OL: Ozone layer depletion; HT: Human toxicity; WT: Fresh water aquatic ecotoxicity; MT: Marine aquatic ecotoxicity; TT: Terrestrial ecotoxicity; PO: Photochemical oxidation.

En el caso del soporte estructural, el elevado impacto ambiental asociado a los procesos de fabricación de los materiales que lo conforman, hace que su contribución al impacto ambiental global de la cubierta sea superior al $50 \%$ en todas las categorías, con valores especialmente críticos en las categorías de "Ecotoxicidad acuática de agua dulce" (95\%), "Ecotoxicidad acuática marina" (90\%), "Ecotoxicidad terrestre" (90\%), "Oxidantes fotoquímicos" (80\%) y "Eutrofización" (70\%). Realizando un análisis de contribución por proceso, se identifica como causante de este impacto el proceso de producción del cemento, debido a los elevados niveles de emisiones y gasto energético asociados.

El subsistema "aislamiento" es el principal responsable del impacto registrado en la categoría de "Agotamiento de la capa de ozono", impacto ocasionado por la fabricación del poliestireno extrudido, empleado como material aislante.

Los impactos ocasionados por el subsistema "acabado superficial" están principalmente asociados al proceso de fabricación del poliéster que constituye el fieltro empleado como mecha de riego, siendo especialmente significativa la categoría de "Toxicidad humana" con una contribución ligeramente superior al 25\%.

El subsistema "impermeabilización" presenta contribuciones inferiores al $10 \%$ en todas las categorías de impacto analizadas. En la figura se observa que el impacto del subsistema "balsa de agua" no resulta significativo.
In the case of the structural support, the high environmental impact associated with the fabrication procedures of the materials which form it, makes its contribution to the roof's global environmental impact over 50\% in all the categories, with particularly critical values in the categories "Fresh water aquatic ecotoxicity" (95\%), "Marine aquatic ecotoxicity" (90\%), "Terrestrial ecotoxicity" (90\%), "Photochemical oxidation" (80\%) and "Eutrophication" (70\%). Carrying out a contribution analysis by process, the cement production process is identified as the cause of this impact, due to the associated high emission levels and energy expenditure.

The "insulation" subsystem is the main cause of the impact registered in the "Ozone layer depletion" category, an impact cause by the fabrication of the extruded polystyrene, used as insulation material.

The impacts caused by the "surface finish" subsystem are mainly associated with the fabrication process of the polyester which makes the felt used as irrigation wick, the "Human toxicity" category being especially significant with a contribution slightly over $25 \%$.

The "waterproofing" subsystem presents contributions lower to $10 \%$ in all the impact categories analysed. The figure shows that the impact of the "water pond" subsystem is not significant. 
Los resultados obtenidos en este primer análisis permiten identificar la importancia del impacto ambiental asociado al soporte estructural. La elección del tipo de estructura sobre el que se apoyará la cubierta es crucial para el impacto del conjunto y, por lo tanto, su optimización ha de ser un elemento de estudio prioritario, si el objetivo es la reducción del impacto ambiental de su construcción.

La estructura puede ser considerada como el elemento común en distintas configuraciones de cubierta, por lo que sería un elemento que quedaría fuera del análisis en un estudio comparativo (aplicando el principio de exclusión de actividades similares en estudios comparativos). Para posibilitar la identificación de los puntos críticos del sistema de cubierta ecológica y poder, posteriormente, comparar su impacto ambiental con diferentes configuraciones, en la Figura 3 se muestran los resultados de la evaluación de impactos de los subsistemas que la conforman, excluyendo la estructura: acabado superficial, aislamiento, balsa de agua e impermeabilización.
The results obtained in this first analysis make possible to indentify the importance of the environmental impact associated with the structural support. The election of the structure type on which the roof will rest is crucial for the overall impact and, therefore, its optimization should be a priority study element, if the objective is the reduction of the environmental impact of its construction.

The structure can be considered as the common element in different roof configurations, becoming an element which would be kept outside of the analysis in a comparative study (applying the exclusion principle of similar activities in comparative studies). In order to enable the identification of the critical points of the ecological roof system and be able to, subsequently, compare its environmental impact with different configurations, Figure 3 shows the results of the impact assessment of the subsystems that form it, excluding the structure: surface finish, insulation, water pond and waterproofing.

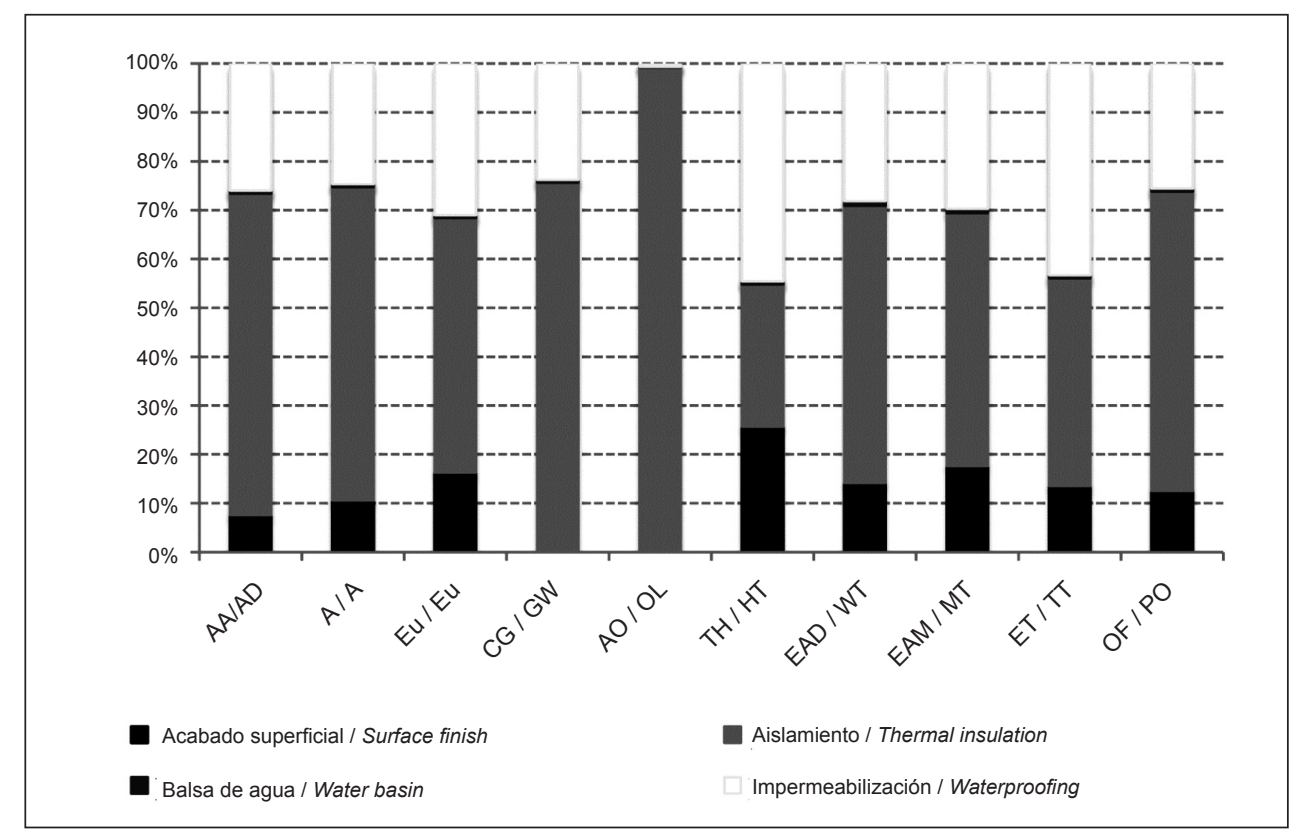

Figura 3. Perfil ambiental de la cubierta (excluyendo la estructura) - Caracterización CML 2000. AA: Agotamiento de recursos abióticos;

A: Acidificación; Eu: Eutrofización; CG: Calentamiento global; AO: Agotamiento de la capa de ozono; TH: Toxicidad humana; EAD: Ecotoxicidad acuática de agua dulce; EAM: Ecotoxicidad acuática marina; ET: Ecotoxicidad terrestre; OF: Oxidación fotoquímica. Figure 3. Environmental profile of the roof (excluding structure) - Characterisation results with CML 2000. AD: Abiotic depletion; A: Acidification; E: Eutrophication; GW: Global warming; OL: Ozone layer depletion; HT: Human toxicity; WT: Fresh water aquatic ecotoxicity; MT: Marine aquatic ecotoxicity; TT: Terrestrial ecotoxicity; PO: Photochemical oxidation.

La Figura 3 permite identificar claramente los elementos de mayor contribución al impacto global del sistema: los resultados de caracterización presentan a los subsistemas "aislamiento" y "acabado superficial" como responsables de la mayor contribución en todas las categorías. El subsistema "aislamiento" es responsable de la mayor contribución en las categorías de "Agotamiento
Figure 3 enables the clear identification of the elements with a larger contribution to the global impact of the system: the characterization results present the "insulation" and "surface finish" subsystems as the ones responsible for the largest contribution in all the categories. The "insulation" subsystem is responsible for the largest contribution in the categories "Ozone layer depletion" 
de la capa de ozono" (95\%), "Calentamiento global" (55\%), "Agotamiento de recursos abióticos" (55\%), "Acidificación" (50\%) y "Oxidantes fotoquímicos" (45\%). El subsistema "acabado superficial" es el principal contribuyente al impacto en "Toxicidad humana", con un $65 \%$ y "Ecotoxicidad acuática marina" y "Ecotoxicidad terrestre", en torno al 45\%. El impacto asociado a la balsa de agua se confirma como despreciable para todas las categorías de impacto analizadas.

\subsection{Evaluación de escenarios}

La modelización del comportamiento ambiental de la cubierta se ha realizado en las cinco ciudades seleccionadas como representativas de las diferentes zonas climáticas establecidas en el CTE, siendo el espesor del aislamiento el parámetro de adaptación.

En la Tabla 4 se resumen los porcentajes de variación del impacto ambiental en todas las categorías para las diferentes zonas climáticas, en relación al impacto asociado a la ciudad de Cádiz, que presenta la menor necesidad de aislamiento.
(95\%), "Global warming" (55\%), "Abiotic depletion" (55\%), "Acidification" (50\%) and "Photochemical oxidation" (45\%). The "surface finish" subsystem is the main contributor to the "Human toxicity" impact, with 65\%, and the "Marine aquatic ecotoxicity" and "Terrestrial ecotoxicity", around 45\%. The impact associated with the water pond is confirmed as negligible for all the analysed impact categories.

\subsection{Scenarios assessment}

The modeling of the roof's environmental performance has been carried out in the five selected cities as representatives of the different climate zones established in the CTE, the adaptation parameter being the insulation thickness.

Table 4 sums up the environmental impact variation percentages in all the categories for the different climate zones, in relation to the impact associated to the city of Cádiz, which presents the lowest insulation need.

Tabla 4 / Table 4

Evaluación de escenarios. Variación en los resultados de caracterización - CML 2000 Scenario assessment. Characterisation results variation with CML 2000.

\begin{tabular}{|c|c|c|c|c|}
\hline Variación respecto a Cádiz / Variation in relation with Cádiz & Valencia & Vigo & Madrid & Soria \\
\hline Agotamiento de recursos abióticos / Abiotic depletion & $0.00 \%$ & $1.43 \%$ & $2.82 \%$ & $4.17 \%$ \\
\hline Acidificación / Acidification & $0.00 \%$ & $1.32 \%$ & $2.60 \%$ & $3.85 \%$ \\
\hline Eutrofización / Eutrophication & $0.00 \%$ & $0.60 \%$ & $1.20 \%$ & $1.78 \%$ \\
\hline Calentamiento global / Global warming & $0.00 \%$ & $2.55 \%$ & $4.97 \%$ & $7.28 \%$ \\
\hline Toxotamiento de la capa de ozono / Ozone layer depletion & $0.00 \%$ & $16.35 \%$ & $28.11 \%$ & $36.97 \%$ \\
\hline Ecotoxicidad acuática de aguanana dulce / Fresh water aquatic ecotoxicity & $0.00 \%$ & $0.46 \%$ & $0.91 \%$ & $1.36 \%$ \\
\hline Ecotoxicidad acuática marina / Marine aquatic ecotoxicity & $0.00 \%$ & $0.20 \%$ & $0.40 \%$ & $0.60 \%$ \\
\hline Ecotoxicidad terrestre / Terrestrial ecotoxicity & $0.00 \%$ & $0.26 \%$ & $0.52 \%$ & $0.77 \%$ \\
\hline Oxidación fotoquímica / Photochemical oxidation & $0.00 \%$ & $0.14 \%$ & $0.28 \%$ & $0.42 \%$ \\
\hline
\end{tabular}

En la tabla se puede apreciar que las variaciones registradas son inferiores al $10 \%$ para todas las categorías de impacto, con la excepción de la categoría "Agotamiento de la capa de ozono". Para poder observar si el porcentaje de variación resulta significativo desde el punto de vista global, en la Figura 4 se muestran los resultados de normalización, obtenidos con la metodología CML 2000, para las cinco zonas climáticas estudiadas. Se puede observar gráficamente en esta representación la mínima incidencia de la modificación en la cantidad de aislamiento en el conjunto del impacto de la cubierta.

Se puede concluir, por tanto, que la variación en la cantidad de material aislante necesaria para cumplir los
The table shows that the variations registered are fewer than $10 \%$ for all the impact categories, with the exception of the "Ozone layer depletion" category. In order to observe if the variation percentage is significant from a global point of view, Figure 4 shows the normalization results, obtained with the CML 2000 methodology, for the five climate zones studied. The minute incidence of the modification of the quantity of insulation in the whole roof impact can be graphically observed in this representation.

In conclusion therefore, the variation in the quantity of the insulation material necessary to satisfy the CTE's 
requisitos del CTE no produce cambios significativos en los resultados de impacto ambiental de la construcción de la cubierta. requirements does not cause significant changes in the environmental impact results of the roof's construction.

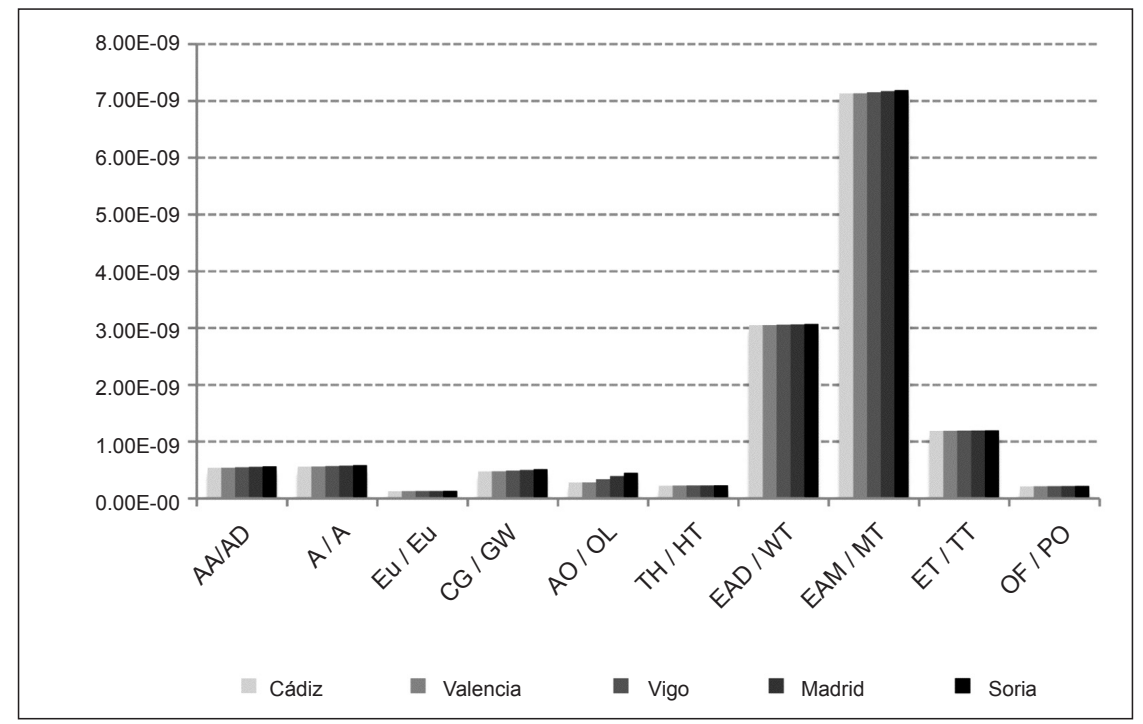

Figura 4. Análisis comparativo en diferentes zonas climáticas - Normalización CML 2000. AA: Agotamiento de recursos abióticos; A: Acidificación; Eu: Eutrofización; CG: Calentamiento global; AO: Agotamiento de la capa de ozono; TH: Toxicidad humana; EAD: Ecotoxicidad acuática de agua dulce; EAM: Ecotoxicidad acuática marina; ET: Ecotoxicidad terrestre; OF: Oxidación fotoquímica. Figure 4. Comparative assessment of different climatic zones - Normalisation results wih CML 2000. AD: Abiotic depletion; A: Acidification; E: Eutrophication; GW: Global warming; OL: Ozone layer depletion; HT: Human toxicity; WT: Fresh water aquatic ecotoxicity; MT: Marine aquatic ecotoxicity; TT: Terrestrial ecotoxicity; PO: Photochemical oxidation.

\subsection{Estrategia de ecodiseño}

Un análisis en profundidad de los materiales que conforman la cubierta, atendiendo a las funciones que desempeñan (subsistema del que forman parte), permite definir una estrategia de ecodiseño que minimice eficazmente el impacto ambiental de la construcción de la cubierta. Una vez se ha optimizado la estructura, los subsistemas que contribuyen de forma más significativa a las distintas categorías de impacto son el "acabado superficial" y el "aislamiento".

En el subsistema de "acabado superficial" cabe destacar la elevada contribución del fieltro empleado como mecha de riego, asociado a la fabricación del poliéster. El empleo de otro tipo de fieltro podría reducir el impacto debido al mismo. Actualmente se está empleando este tipo de fieltro por su probada durabilidad, pero se recomienda el estudio de otras alternativas.

El subsistema "aislamiento" está formado por la Losa Filtrón y los soportes que sirven de apoyo a la misma. La Losa Filtrón es la responsable de la mayor contribución al impacto, asociado a la fabricación del poliestireno extrudido, por lo que el empleo de otro tipo de material aislante permitiría alcanzar una reducción considerable del impacto de este subsistema. Las cubiertas invertidas están diseñadas de forma que el aislamiento térmico

\subsection{Ecodesign strategy}

An in-depth analysis of the materials forming the roof, taking into account the roles they play (the subsystem they're a part of) makes possible to define an ecodesign strategy which minimizes effectively the environmental impact of the roof's construction. Once the structure has been optimized, the subsystems contributing most significantly to the different impact categories are the "surface finish" and the "insulation" ones.

In the "surface finish" subsystem, the high contribution of the felt used as irrigation wick is worth emphasizing, associated to polyester fabrication. The use of another type of felt could reduce its impact. Presently this type of felt is being used because of its proven durability, but the study of other alternatives is encouraged.

The "insulation" subsystem is formed by the Filtrón Slab and the supports on which it rests. The Filtrón Slab is responsible of the highest contribution to the impact, associated with the fabrication of extruded polystyrene, therefore the use of another type of material would make possible to achieve a considerable reduction of this subsystem's impact. Reversed roofs are designed so that the thermal insulation can be affected by the exterior 
puede verse afectado por las condiciones del ambiente exterior, por lo que es necesario profundizar en el estudio de un material alternativo al que no le perjudiquen estas condiciones.

En el subsistema "impermeabilización" la contribución a las distintas categorías de impacto está repartida entre los tres componentes del subsistema: lámina de PVC, fieltro de poliéster y mortero. De nuevo sería de gran interés estudiar alternativas para el fieltro; la optimización en el uso del mortero, disminuyendo su espesor, se presenta como una vía complementaria de disminución del impacto.

\section{CONCLUSIONES}

Resulta evidente que en los próximos años el sector de la construcción ha de realizar un notable esfuerzo de adaptación a las pautas que definirán una nueva forma de entender el proceso constructivo, donde la sostenibilidad cobrará sin duda especial protagonismo. En un claro escenario futuro de incremento de exigencias, tanto en el sentido de mejora de la sostenibilidad de la edificación como de transparencia en la comunicación de la información al respecto, la norma europea de evaluación de la sostenibilidad de los edificios se constituirá indiscutiblemente como el elemento de referencia en el contexto europeo, siendo el Análisis de Ciclo de Vida (ACV) el método establecido para evaluación del comportamiento ambiental.

Los esfuerzos de mejora del comportamiento de la edificación han de centrarse en el aumento de la eficiencia energética, factor clave para disminuir su impacto ambiental, analizando en profundidad la fase de construcción de las medidas propuestas para garantizar que se produce una mejora de comportamiento desde un punto de vista global. En el presente estudio se ha empleado la metodología de ACV con el objetivo de cuantificar el impacto ambiental de los materiales que componen la cubierta vegetal, analizando en profundidad el perfil ambiental de la cubierta, como punto de partida para poder analizar las repercusiones ambientales que conlleva su implementación en los diferentes contextos climáticos de España. Los resultados obtenidos permiten identificar la importancia del impacto ambiental asociado al soporte estructural: la elección del tipo de estructura sobre el que se apoyará la cubierta es crucial para el impacto del conjunto y, por lo tanto, su optimización ha de ser un elemento de estudio prioritario.

Si se considera la estructura como el elemento común en distintas configuraciones de cubierta, por lo que quedaría fuera del análisis en un estudio comparativo, los subsistemas que contribuyen de forma más significativa environment conditions, and therefore it is necessary to study in depth an alternate material which won't be affected by these conditions.

In the "waterproofing" subsystem the contribution to the different impact categories is shared by the three subsystem's component: PVC sheet, polyester felt and mortar. Once again, studying alternatives for the felt use would be quite interesting; the optimization in the mortar use, reducing its thickness, is presented as a complementary way for the impact's reduction.

\section{CONCLUSIONS}

It seems clear that in the next years the construction sector must make a notable effort to adapt to the guidelines which will define a new way of understanding the building process, where sustainability will undoubtedly become specially prominent. In a clear future scenario of increasing demands, both in the sense of improving building sustainability and the transparency in communicating the information on the matter, the European standard for the assessment of buildings sustainability will unarguably become the element of reference in the European context, with Life Cycle Assessment (LCA) as the established environmental performance assessment method.

The efforts to improve the building performance must be focused in the increase of the energy efficiency, a key factor to reduce their environmental impact, analysing in depth the construction phase of the measures proposed to guarantee that a performance improvement takes place from a global point of view. In this study the LCA methodology has been used with the aim of quantifying the environmental impact of the materials forming the green roof, analysing in depth the roof's environmental profile, as a starting point to be able to analyse the environmental repercussions that its implementation in the different climate contexts in Spain entails. The results obtained make possible to identify the importance of the environmental impact associated with the structural support: the selection of the type of structure on which the roof will rest is crucial for the whole impact and, therefore, its optimization should be a priority study element.

If the structure is considered as the common element in different roof configurations, and therefore it would be outside of the analysis in a comparative study, the subsystems contributing in the most significant way to 
a las distintas categorías de impacto son los de "acabado superficial" y "aislamiento". En el subsistema de "acabado superficial" cabe destacar la elevada contribución del fieltro empleado como mecha de riego, asociado a la fabricación del poliéster. Actualmente se está empleando este tipo de fieltro por su probada durabilidad, pero se recomienda el estudio de otras alternativas. En el subsistema "aislamiento", la mayor contribución al impacto ambiental está asociada a la fabricación del poliestireno extrudido, por lo que el empleo de otro tipo de material aislante permitiría alcanzar una reducción considerable del impacto de este subsistema.

\section{AGRADECIMIENTOS}

Los autores quieren expresar su agradecimiento a la empresa Intemper Española, S.L., por el financiamiento y la estrecha colaboración con el trabajo de investigación, dentro de la Cátedra UPM INTEMPER "Cubiertas y Fachadas Sostenibles". the different impact categories are those of "surface finish" and "insulation". In the "surface finish" subsystem, the high contribution of the felt used as irrigation wick, associated with polyester fabrication, is worth noting. Presently this type of felt is being used because of its proven durability, but the study of other alternatives is encouraged. In the "insulation" subsystem, the highest contribution to the environmental impact is associated with the fabrication of extruded polystyrene, and therefore the use of another type of insulating material would make possible to achieve a considerable reduction of this subsystem's impact.

\section{ACKNOWLEDGEMENTS}

The authors wish to thank the company Intemper Española S.L., for financing and working closely with the research work within the UPM INTEMPER Chair "Sustainable Roofs and Façades"

\section{BIBLIOGRAFÍA / BIBLIOGRAPHY}

(1) IPCC: Cambio climático 2007: Informe de síntesis. Contribución de los Grupos de trabajo I, II y III al Cuarto Informe de evaluación del Grupo Intergubernamental de Expertos sobre el Cambio Climático. Geneva, Switzerland (2007).

(2) United Nations Environment Programme Sustainable Building Initiative: Submission to the Ad Hoc Working Group on Long-Term Cooperative Action under the Convention (AWG-LCA) (2009).

(3) UNESCO: Nota introductoria al Programa en pro de la Ciencia de la UNESCO: Marco General de Acción (1999)

(4) Nemry, F.; Uihlein, A.: Environmental Improvement Potentials of Residential Buildings (IMPRO-Building). JRC Scientific and Technical Report. European Commission, Joint Research Centre, Institute for Prospective Technological Studies (2008).

(5) Greater London Authority. Living Roofs and Walls. Technical Report: Supporting London Plan Policy (2008).

(6) Carter, T.; Fowler, L.: "Establishing Green Roof Infrastructure Through Environmental Policy Instruments". Environ. Manage., vol. 42, no 1 (2008), pp. 151-164. doi:10.1007 / s00267-008-9095-5.

(7) Takebayashi, H.; Moriyama, M.: "Surface heat budget on green roof high reflection roof for mitigation of urban heat island". Build. Environ., vol. 42, no 8 (2007), pp. 2971-2979. doi:10.1016 / j.buildenv.2006.06.017.

(8) Kumar, R.; Kaushik, S. C.: "Performance evaluation of green roof and shading for thermal protection of buildings". Build. Environ., vol. 40, no 11 (2005), pp. 1505-1511. doi:10.1016 / j.buildenv.2004.11.015.

(9) Machado, M.; Brito, C.; Neila, F. J.: "La cubierta ecológica como material de construcción". Inf. Constr., vol. 52 , no 467 (2000), pp. 15-29. doi:10.3989 / ic.2000.v52.i467.705.

(10) Neila, F. J.; Bedoya, C.; Acha, C.; Olivieri, F.; Barbero. M.: "Las cubiertas ecológicas de tercera generación: un nuevo material constructivo". Inf. Constr., vol. 60, no 511 (2008), pp. 15-24. doi:10.3989 / ic.2008.v60.i511.742.

(11) Saiz, S.; Kennedy, C.; Bass, B.; Pressnail, K.: "Comparative Life Cycle Assessment of Standard and Green Roofs". Environ. Sci. Technol., vol. 40 (2006), pp. 4312-4316.

(12) Macías, M.; García Navarro. J.: "Metodología y herramienta verde para la evaluación de la sostenibilidad en edificios". Inf. Constr., vol. 62, no 517 (2010), pp. 87-100. doi:10.3989 / ic.08.056.

(13) Rivela, B.; Moreira, M. T.; Muñoz, I.; Rieradevall, J.; Feijoo, G.: "Wood Waste from Ephemeral Architecture: Using Life Cycle Assessment to Identify the Best Choice". Sci. Total Environ., vol. 357, no 1-3 (2006), pp. 1-11. doi:10.1016 / j.scitotenv.2005.04.017.

(14) Norma UNE-EN ISO 14040:2006. Gestión ambiental. Análisis de ciclo de vida. Principios y marco de referencia.

(15) EN 15643-1 Sustainability of construction works - Integrated assessment of building performance. Part 1: General framework.

(16) EN 15643-2 Sustainability of construction works - Assessment of buildings - Part 2: Framework for the assessment of the environmental performance.

(17) EN 15978 Sustainability of construction works - Assessment of environmental performance of buildings - Calculation methods.

(18) Tomerius, C.: Meydan Shopping Square. A new prototype by FOA. A Metro Group Project in Istanbul. Jovis (2007). 
(19) Guinée, J. B.; Gorreé, M.; Heijungs, R.; Huppes, G.; Kleijn, R.; de Koning, A.; van Oers, L.A.; Weneger, A.; Suh, S.; Udo de Haes, H.A.; de Bruijn, H.; van Duin, R.; Huijbregts, M.: Life cycle assessment: An operational guide to the ISO standards. Leiden, Netherlands (2001).

(20) Norma UNE-ISO 21930:2010 Sostenibilidad en la construcción de edificios. Declaración ambiental de productos de construcción.

(21) EN 15804 Sustainability of construction works - Environmental product declarations - Product category rules.

(22) ILCD Handbook. International Reference Life Cycle Data System. General guide for Life Cycle Assessment. Detailed guidance. European Commission, Joint Research Centre, Institute for Environment and Sustainability (2010).

(23) Hischier, R.; Althaus H. J.; Bauer, Chr.; Doka, G.; Frischknecht R.; Jungbluth N.; Margni M.; Nemecek, T.; Simons A.; Spielmann M.: Documentation of changes implemented in ecoinvent Data v2.1. Final report ecoinvent data v2.1. volume: 16. Swiss Centre for LCI. Dübendorf. CH (2009). 